\title{
ANALYSIS OF ECONOMIC EFFICIENCY IN COCOA PRODUCTION IN GHANA
}

A neani $\mathrm{F}^{*}{ }^{1}$, Anchirinah $\mathrm{VM}^{1}$, A samoah $\mathrm{M}^{1}$ and $\mathrm{F}$ O wusu-Ansah ${ }^{1}$

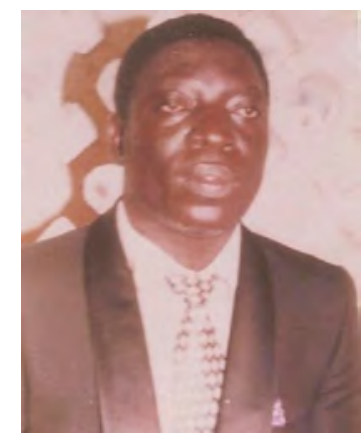

Fransis A neani

*Corresponding author email: franeani@yahoo.com

${ }^{1}$ Cocoa Research Institute of Ghana, Social Science and Statistical Unit, P. O. Box 8, New Tafo-Akim, Ghana. 


\section{ABSTRACT}

The main purpose of this study was to analyze the economic efficiency of resource utilization in cocoa production of the cocoa farmers in Ghana to provide information for effective application and management of farm inputs on cocoa farms and policy recommendation. A random sample of 300 farmers in the Eastern, Ashanti, BrongAhafo, Central, Volta and Western regions of Ghana were selected, using the multistage sampling approach. Individual farmers were interviewed by using questionnaires. Descriptive and inferential analyses of the survey data were performed. Regression analysis was employed to estimate the Cobb-Douglas production function from the farm data for the measurement of technical efficiency of the cocoa farmers. The estimated elasticity from the production function and prices of input and output were subsequently used to calculate the measures of allotment efficiency of resource use by the farmers. The coefficients for household size, cocoa farm size, quantity of insecticides, quantity of fungicides, and quantity of fertilizer were $0.261,0.514,0.273,0.090$ and 0.325 , respectively. The quantity of fertilizer applied to the cocoa farm had the highest marginal physical product $(133.11 \mathrm{~kg} / \mathrm{bag})$, and that of quantity of fungicides variable $(1.39 \mathrm{~kg} / \mathrm{satchet})$ was lowest. Household size, farm size, insecticides, fungicides and fertilizer were found to have statistically significant impact on cocoa output. The sum of elasticities of the factors included in the Cobb-Douglas production function was 1.463, which was more than one, implying that the cocoa farmers were operating in the increasing returns to scale. There were incidences of inefficiencies in the management of resources in cocoa cultivation by cocoa farmers since some resources were underutilized and others over-utilized. Farmers are advised to increase the use of household members, insecticides, fungicides and fertilizer while reducing the use of forest land through increased land productivity instead of land expansion to ensure efficient use of resource in cocoa production. However, the environmental impacts of these farm activities should be assessed to ensure sustainable cocoa production.

K ey words: cocoa, survey, production, efficiency, Ghana 


\section{INTRODUCTION}

The cocoa industry, which is partially liberalized and with strong government involvement as indicated by the regulatory role of Ghana Cocoa Board (COCOBOD), holds a unique position in Ghana's economy as one of the important sectors for international trade. Cocoa is a major foreign exchange earner and the industry has played a crucial role in the development of Ghana in agriculture, health, education and other services. Government ensures efficient and sustainable cocoa cultivation, development of cocoa production and marketing technologies, production of good quality cocoa beans, transportation of the beans from the buying centres to the ports for export. The government tends to focus attention on the control of pests and diseases of cocoa, provision of planting materials, addressing of land tenure issues of cocoa farming and cocoa marketing problems. Research has shown that cocoa farmers can produce cocoa yields of $1000 \mathrm{~kg} / \mathrm{ha}$ or more [1]. However, the national average yield produced by the farmers is $400 \mathrm{~kg} / \mathrm{ha}$ with the assistance of the government cocoa policies of Cocoa Diseases and Pests Control (CODAPEC) and the Cocoa High Technology (Hitech) Programmes implemented since 2001. These programmes were not targeted at a certain number of cocoa farmers. CODAPEC involved the spraying of farmers' crops with insecticides and fungicides to control capsids and blackpod disease, respectively by spraying gangs employed by the government (COCOBOD). The Cocoa High Technology Programme also involved providing cocoa farmers with fertilizer, insecticides, fungicides and hybrid cocoa variety on credit for use on cocoa farms. However, the baseline socio-economic survey [1] sampled 300 cocoa farmers for the determination of the adoption rates of the promoted technologies, that is, assessing the impact of the programmes. The adoption rate expected by the study was $50 \%$. For instance, the adoption rates of the recommended technologies like control of capsids with insecticides, control of black pod disease with fungicides, weeding of the farms manually or with herbicides, planting hybrid cocoa variety and fertilizer application were $10.3 \%, 7.5 \%, 3.7 \%, 44.0 \%$ and $33.0 \%$, respectively [1]. The problem of low yield relative to the potential has been ascribed to some constraints such as diseases and pests, low adoption of the cocoa production technologies, inefficiency in the use and allocation of resources. Also, farmers might use resources rationally but not at the economic optimal level. This situation explicitly indicates that to be able to achieve the COCOBOD target of one million ton of cocoa beans in 2012, the identification of the factors responsible for enhancing cocoa productivity is important. It also calls for a detailed examination of the farm efficiency in terms of technical, allotment and economic efficiencies for increasing productivity. However, with the low rates of adoption of cocoa technologies by farmers due to resource inadequacy among other reasons, efficiency improvement becomes significant factor in increasing productivity [2]. The technical efficiency is the ability of the farm to achieve the maximum possible output with available resources, while the allotment efficiency refers to the ability to obtain optimal allocation of given resources, that is, the ability and willingness of economic unit to equate its specific marginal value product with its marginal cost. Economic efficiency is the combination of both the technical and allotment efficiencies. The measurement of economic efficiency is thus not complete without a study of technical and allotment efficiencies and it is the frontier production 
function that enables the measurement of these efficiencies of farmers [3]. Quantification of these measures is useful in three ways: they facilitate comparisons across similar economic units; where measurements reveals variation in efficiencies among economic units, further analysis can be undertaken to identify the factors causing these variations; and such analyses have policy implications for the improvement of efficiencies. The specification and evaluation of the impact of the inputs on output distribution is important for policy making and agricultural production technology promotion strategies as farmers can affect the distribution of output and thus income by varying the levels and combination of inputs employed in production as noted by Kalirajan and Shaud [4]. Production function analysis for estimation of efficiency of resource use in crop production systems and determination of the optimal resource allocation for adjustment in resource allocation has been employed in some studies [5, 6]. They reported that there was inefficiency in the use of resources. Hence, adjustments in resource allocation for economic optimum might be required to meet the needed percentage change based on the equality of marginal value products and marginal factor costs of inputs.

Cocoa Research Institute of Ghana (CRIG) implemented the Ghana Cocoa Farmers' Newspaper Project, in collaboration with Cadbury International Limited, to provide extension information on CRIG-recommended cocoa production technologies to farmers for adoption to increase cocoa output. To assess the impact of this project, a baseline survey was conducted in 2006 to investigate the actual farm practices of the cocoa farmers and the adoption levels of CRIG-recommended technologies. There has been a problem of inadequate maintenance of cocoa farms in terms of control of pests and diseases and of low fertility of soils. This is due to inadequate use of production inputs and low adoption of improved technologies by farmers because of insufficient money for the purchase of the inputs. For instance, farmers on average weed their farms twice in a year instead of four times. They control capsids and blackpod disease by spraying twice instead of four and nine times per annum, respectively. Inefficiency in resource use on cocoa farms has been a current concern of CRIG/COCOBOD. Hence, the main purpose of this study was to analyze the economic efficiency of resource utilization in cocoa production of cocoa farmers in Ghana to provide information for effective application and management of farm inputs on cocoa farms and for policy advice. The specific objectives set for this investigation were to: 1) estimate the stochastic production frontier of cocoa farming; 2) measure the marginal productivity of the cocoa production factors and 3) determine the efficiency of resource utilization in cocoa production.

This paper presents the survey methods and analytical techniques, discusses survey results and draws conclusions on the analysis of the resource utilization data from the survey. 


\section{METHODOLOGY}

\section{Study Areas}

The study areas included Atwima Mponua, Asunafo North (Goaso), Aowin/ Suaman (Enchi), Birim South (Oda), Twifo/Assin Fosu and Hohoe districts (Fig. 1). These districts share some common features with respect to rainfall, temperature, height above sea level and socio-economic activities. The average rainfall amount ranged from 945.7 to $2000 \mathrm{~mm}$ in 2006 and the mean temperature figures between 22 and $34^{\circ} \mathrm{C}$. The height above sea level also ranges between 61 and $890 \mathrm{~m}$. In addition, the vegetation types are moist semi-deciduous rain forest and Savannah. The main socioeconomic activities in the districts are farming, trading, logging, small-scale mining and quarrying. Moreover, the key crops grown in the district, with their respective mean farm sizes in parentheses, comprises of cocoa (2.8 ha), coffee (1.2 ha), citrus (1.8 ha), oil palm (2.2 ha) and food crops such as maize (1.1 ha), cassava ( $0.8 \mathrm{ha})$, rice (1.2 ha), yam ( $0.4 \mathrm{ha})$, and plantain (1.2 ha). The farming activities undertaken by cocoa farming households include farm establishment involving land clearing and preparation as well as planting of seeds (seedlings); farm maintenance entailing weeding and control of pests and diseases; crop harvesting; and storage and sale of farm produce.

\section{Sampling and data collection}

A random sample of 300 cocoa farmers in the Eastern, Ashanti, Brong-Ahafo, Central, Volta and Western regions of Ghana were selected, using the multi-stage sampling approach [7, 8]. A questionnaire was used for individual personal interview from March to May, 2006. The sample size was determined by using the standard deviation of 16.3 years obtained from the age variable of a previous survey to achieve a precision of 0.94 (standard error of the mean) for the current study [9]. The cocoa farmers were selected from households in 57 farming communities in the districts. The multi-stage sampling procedure entailed selecting six cocoa growing regions, one districts per region, five villages per district and ten farmers per village as the sampling units in each stage. A list of names of farmers of the Licensed Buying Companies (LBCs) served as the sampling frame for a sample of cocoa farmers. 
MAP INDICATING THE VARIOUS DISTRICTS WHERE THE BASE LINE SURVEY ON THE GHANA COCOA FARMERS NEWS PAPER WAS CONDUCTED

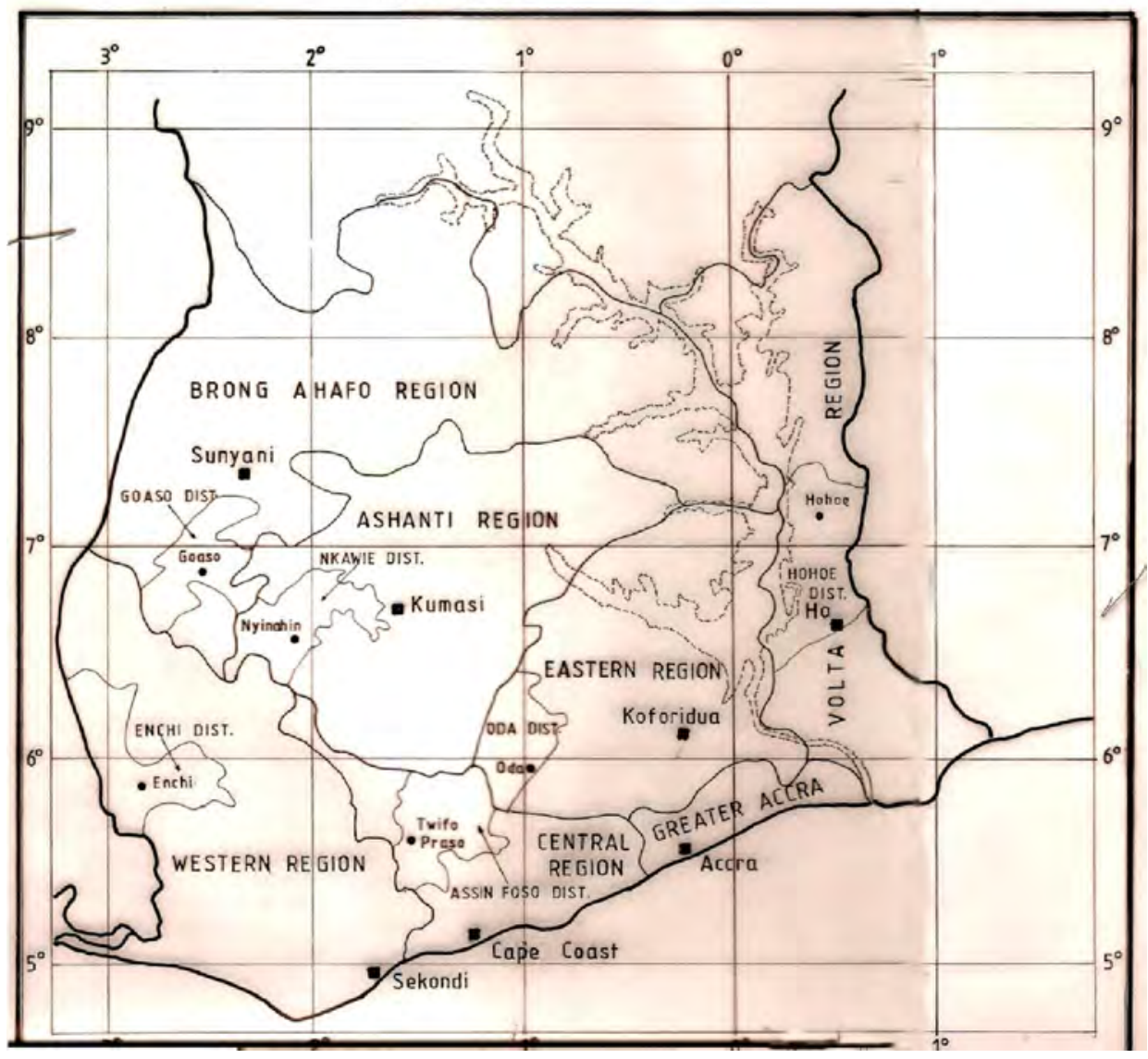

Figure 1: M ap showing the various districts where the baseline survey was conducted.

The data collection involved individual interviews with selected farmers using a questionnaire which covered issues such as personal information, farm management practices, farm income, credit, technology adoption, constraints to cocoa production and extension. The questionnaire was pre-tested with a group of farmers to address fundamental problems in the survey design such as difficulties in question wording, problems with leading questions and bias due to question order. Six enumerators and three supervisors were selected and trained on how to administer the questionnaires efficiently. The professional background of the interviewers included agricultural economist, biometrician, sociologist and technical officers. Descriptive and inferential analyses of the survey data were performed. 


\section{Analytical Framework}

\section{M easurement of Technical efficiency}

Technical efficiency in production is the physical ratio of output to the factor input. The production function is a function that summarizes the conversion of inputs of capital, labour and other factors into outputs of goods and services [10]. The production function approach is employed widely for examining the impact of physical inputs on production. A stochastic frontier model (using Cobb-Douglas production function) is specified as [11]:

$\mathrm{Y}_{\mathrm{i}}=\mathrm{X}_{\mathrm{i}} \beta+\mathrm{v}_{\mathrm{i}}-\mathrm{u}_{\mathrm{i}}$

Where,

$Y_{i}=$ output of cocoa farmer

$\mathrm{X}_{\mathrm{i}}=\mathrm{a}(1 \mathrm{x} \mathrm{k})$ vector of farm inputs (in natural logarithm)

$\beta=\mathrm{a}(\mathrm{k} \times 1)$ vector of parameters to be estimated

$v_{i}=$ the random variation in output $\left(Y_{i}\right)$ due to factors outside the control of the farm such as weather and natural disasters

$\mathrm{u}_{\mathrm{i}}=$ the factors (within the control of the farmer) responsible for that farmer inefficiency such as management

$\mathrm{V}_{\mathrm{i}}$ is assumed to be identically and independently distributed as $\mathrm{N}\left(0, \sigma_{\mathrm{v}}{ }^{2}\right)$ random variables, independent of $u_{i}$ which is distributed as a truncated normal (at zero) of the $\mathrm{N}\left(\mathrm{u}_{\mathrm{i}}, \sigma^{2}\right)$ distribution. $\mathrm{u}_{\mathrm{i}}$ is independently, but not identically distributed. In general, $\mathrm{e}_{\mathrm{i}}$ $=v_{i}-u_{i}$ is the composed error term. The technical inefficiency effect model can only be estimated if the efficiency effects are present. If the one-sided error term in the production function is not present then our model is an ordinary production function, which can be estimated by Ordinary Least Squares (OLS) regression technique. Otherwise, if $u_{i}$ is present it implies that it is justifiable to employ the stochastic frontier approach.

A Cobb-Douglas function was fitted to the stochastic frontier production and estimated. This functional form has been employed consistently in related efficiency studies $[12,13,14]$. A more flexible form like the translog function can also be used [15]. The Cobb-Douglas function is employed because it is commonly used in the literature, making estimates comparable with previous studies. The specified multiplicative production function was:

$Q=A \cdot X_{1}^{\beta 1} \cdot X_{2}^{\beta 2} \cdot X_{3}^{\beta 3} \cdot X_{4}^{\beta 4} \cdot X_{5}^{\beta 5} \cdot E$ 
The linear transformation of (2) is achieved by taking the natural logarithm of both sides of the equation to obtain (3).

$\operatorname{In} Q=\beta_{0}+\beta_{1} \operatorname{In} X_{1}+\beta_{2} \operatorname{In} X_{2}+\beta_{3} \operatorname{In} X_{3}+\beta_{4} X_{4}+\beta_{5} \operatorname{In} X_{5}+e$

Where:

$\mathrm{Q}$ = Cocoa output in kilogrammes; $\mathrm{X}_{1}=$ Household size (number of household members) $(+) ; X_{2}=$ Cocoa farm size in hectares $(+) ; X_{3}=$ Quantity of insecticides in litres $(+) ; X_{4}=$ Quantity of fungicides in satchets $(+) ; X_{5}=$ Quantity of fertilizer in bags $(+) ; \quad \beta_{\mathrm{i}}=$ Parameters (elasticities) to be estimated; $\mathrm{e}=$ Composite error term, defined as $\mathrm{v}-\mathrm{u}$ in equation (1).

Labour could not be measured in man-days or hours since the questionnaire did not capture this as it was not designed for that. However, labour was proxied with household size which provides approximate information on the labour available to the farmer since they tend to use household members for performing their farm activities. Land was too broad to measure since traditionally it comprises of the various natural resources available to the farmer. So it was decided to proxy it with cocoa farm size which was easy to measure and represents the actual land area under cocoa production. Opportunity costs were not considered in this study. The quantity of insecticides and fungicides were selected as inputs since they are used to control insect pests (capsids) and fungal diseases (blackpod diseases) attacking the cocoa trees. It is assumed that the more quantity the farmer sprays, the better pests and diseases are controlled. Hence, the more pods that the healthy cocoa trees can produce. The cocoa farmers also use fertilizer on their farms to improve the soil fertility to boost cocoa production. The assumption here is that cocoa soils in Ghana are depleted of plant nutrients due to soil mining from prolonged cocoa cultivation. Hence, an increase in the quantity of fertilizer applied to the soil would result in higher cocoa yields.

When all factors of production are increased, it implies a change in the scale of operations (such as change in economies of scale). This can lead to one of the following situations:

For constant returns to scale, $\beta_{1+} \beta_{2}+\beta_{3}+\beta_{4}+\beta_{5}=1$, that is, if all the inputs are increased by a factor of $n$, then the output also increases by a factor of $n$. For increasing returns to scale, $\beta_{1+} \beta_{2}+\beta_{3}+\beta_{4}+\beta_{5}>1$, if all the inputs are increased by a factor of $n$, then the output increases by an amount greater than $n$. For decreasing returns to scale, $\beta_{1+} \beta_{2}+\beta_{3}+\beta_{4}+\beta_{5}<1$, if all the inputs are increased by a factor of $n$, then output increases by an amount less than $n$.

\section{M easurement of Allotment Efficiency}

Allotment efficiency occurs when a firm chooses resources and enterprises in such a way that a given resource is considered efficiently utilized in production if its marginal value product (MVP) is equal to its marginal factor cost (MFC) $[10,14]$.

$\mathrm{MVP}_{\mathrm{i}}=\mathrm{MFC}_{\mathrm{i}}=\mathrm{P}_{\mathrm{xi}}$ 
Efficiency of resource use was determined by the ratio of MVP to MFC of inputs based on the estimated regression coefficients. The efficiency of resource use, $r$, was calculated as [16]:

$\mathrm{r}=\mathrm{MVP} / \mathrm{MFC}$

The rule of thumb is that when $r=1$, there is efficient use of a resource; $r>1$ shows under utilization; while $r<1$ means over utilization of resource. The values of MVP and MFC were estimated as follows:

$\mathrm{MVP}=\mathrm{MPP} . \mathrm{P}_{\mathrm{Q}}$

$\mathrm{MPP}=\partial \mathrm{Q} / \partial \mathrm{X}_{\mathrm{i}}$

$\mathrm{MPP}=\beta_{\mathrm{i}} \cdot \mathrm{Q}_{\mathrm{m}} / \mathrm{X}_{\mathrm{mi}}$

$\mathrm{MFC}=\mathrm{P}_{\mathrm{xi}}$

Where,

$\mathrm{r}=$ efficiency ratio; $\mathrm{MVP}=$ marginal value product of the variable input; $\mathrm{MPP}=$ marginal physical product; $\mathrm{MFC}=$ marginal factor cost, $\mathrm{P}_{\mathrm{xi}}$ (Unit price of input $\mathrm{X}_{\mathrm{i}}$ ); $\mathrm{Q}_{\mathrm{m}}=$ mean value of output; $\mathrm{X}_{\mathrm{mi}}=$ mean value of input considered; $\mathrm{P}_{\mathrm{Q}}=$ unit price of output; $\beta_{\mathrm{i}}=$ output elasticities.

The relative resource adjustment needed for optimal allocation of the resources was calculated as follows [17]:

$\mathrm{D}_{\mathrm{i}}=\left(1-\left(\mathrm{MFC}_{\mathrm{i}} / \mathrm{MVP}_{\mathrm{i}}\right)\right) \times 100$

Where,

$D_{i}=$ absolute value of the percentage change in MVP of the ith resource; $M_{F} C_{i}=$ marginal factor cost of the ith resource; $\mathrm{MVP}_{\mathrm{i}}=$ marginal value product of the ith resource.

\section{RESULTS}

\section{Profile of sample cocoa farmers}

A summary of the household characteristics of cocoa farmer is presented in Table 1. The mean age of the farmers was 51.5 years. The mean working experience was 19.6 years. The average number of adults working on the farm was 3.3 people. The educational status of the farmers was low as the majority (52.0\%) had middle school education and $21.5 \%$ of them were illiterates. Considering gender, $80.0 \%$ of the interviewed farmers were males while $20.0 \%$ were females. The mean farm size was 3.0 ha, implying that cocoa cultivation is dominated by small-scale farmers who on 
average had cocoa yield of $370 \mathrm{~kg} / \mathrm{ha}$. The cocoa output variable with mean value of $797.4 \mathrm{~kg}$ had a bigger standard deviation or variance, which might be due to the differences in farm management practices of the cocoa farmers and varying rainfall amounts and its distribution patterns experienced over the years. The mean income from cocoa was $\mathrm{GH} \phi 717.68$ with a high standard deviation of $\mathrm{GH} \notin 820.87$, which was due to the high variation in cocoa output. Cocoa farmers also cultivated food crops (plantain, cassava, maize, cocoyam, yam, rice, banana, pineapple, okro and ginger) and other tree crops (coffee, oil palm, citrus and coconut) with respective average farm sizes of about 1 ha and 2 ha. Cocoa farmers also reared some poultry and livestock such as fowls, pigs, sheep and goats for home consumption and sale. However, the data from the survey did not allow for the estimation of income from the other crops and livestock of the farmers.

\section{Technical E fficiency of Resource Use}

The summary statistics of output and input variables in cocoa production is also presented in Table 1. Table 2 summarizes the farm size of other crops planted by cocoa farmers. The results of the OLS estimates of the Cobb-Douglas production function are in Table 3. The attempt made in estimating the stochastic frontier model based on Cobb-Douglas production function was not successful. This was due to the absence of the one-sided error term, $\mathrm{U}_{\mathrm{i}}$, in the model as indicated by the statistically insignificant sigma-squared $\left(\sigma^{2}\right)$ and gamma $(\gamma)$ figures (Table 4$)$. This implied that the ordinary least square estimation would be adequate representation of the data $[2$, 18]. Therefore, ordinary production function was estimated using the OLS regression analysis. Although the survey interviewed 300 farmers, the different figures of the total numbers of farmers ( $n$ ) used in the summaries occurred because there were missing values and these led to the pairwise elimination of some of the cases during the analysis. The F-test was statistically significant at the $1 \%$ level, meaning that the production function existed; that is, all the explanatory variables jointly explained the variations in the output. The R-squared was 0.623 , indicating that $62.3 \%$ of the variation in the cocoa output was explained by the independent variables included in the model. Autocorrelation was absent in the data as shown by the Durbin-Watson statistic of 2.381 .

All the independent variables emerged significant. The intercept, cocoa farm size, quantity of insecticides and quantity of fertilizer were significant at the $1 \%$ level. The household size and quantity of fungicides were significant at the $10 \%$ level. The signs of all the coefficients of the explanatory variables were positive as expected. The coefficients estimate the elasticity of cocoa output. For instance, a $10 \%$ increase in household size, farm size, quantity of insecticides, quantity of fungicides and quantity of fertilizer resulted in $2.61 \%, 5.14 \%, 2.73 \%, 0.9 \%$ and $3.25 \%$ increase in cocoa output, respectively. The sum of elasticities of the factors in the Cobb-Douglas production function was 1.463 , which was more than one, implying that the cocoa farmers were operating in the increasing returns to scale. 


\section{Allotment Efficiency of R esource U se}

The results of the marginal analysis of input utilization are summarized in Table 5. The quantity of fertilizer applied to the cocoa farm had the highest marginal physical product $(133.11 \mathrm{~kg} / \mathrm{bag})$, followed by cocoa farm size $(126.31 \mathrm{~kg} / \mathrm{ha})$, the quantity of insecticides (30.49 kg/litre), household size $(22.64 \mathrm{~kg} /$ person) and finally, the quantity of fungicides variable $(1.39 \mathrm{~kg} / \mathrm{satchet})$. The household size, insecticides, fungicides, and fertilizer were underutilized for cultivation of cocoa since their corresponding ' $r$ ' figures were more than one. For optimal resource allocation in cocoa production, they should be increased by $92.84 \%, 62.04 \%, 83.33 \%$ and $94.89 \%$ from the current levels, respectively. However, land represented by cocoa farm size was over-utilized due to the fact that its ' $r$ ' estimate was less than one and its use should be reduced by $83.0 \%$ to ensure efficient production.

\section{DISCUSSION}

This study demonstrated that the estimated coefficients of the Cobb-Douglas production function are elasticities of cocoa production factors such as household size, farm size, insecticides, fungicides and fertilizer which had statistically significant and positive impact on cocoa output. The elasticities represent the ratio of the percentage change in cocoa output to the percentage changes in the respective levels of the factors of cocoa production. The sum of the elasticities being greater than one implied increasing return to scale. For instance, $100 \%$ increase in all the factor levels would result in $146.3 \%$ increase in cocoa output. The positive values of the MPPs of the production resources also emphasize the importance of these resources in cocoa cultivation. This means that these variables or factors are important in increasing cocoa production. Therefore, the government may emphasize the use of these factors in cocoa cultivation.

The sample farmers have enough experience in cocoa cultivation to enable them to manage their farms properly. However, the mean age implies that cocoa farmers in Ghana are aged and their age could affect cocoa output since they might not have adequate strength to perform the farming activities. Thus, they can employ more adult household members to perform their farming activities.

Generally, cocoa production is profitable. However, cocoa farmers who mismanaged their farms usually incur losses. It has been observed that maximization of profit in cocoa production, using improved technologies, is associated with increasing cost of production. This observation can be substantiated with empirical evidence from the baseline socio-economic and farm management survey: that improved production practices increased cocoa yield, cocoa income, cost of production of cocoa and profit [1].

Further, the study showed that the household size, insecticides, fungicides, and fertilizer were underutilized for cocoa cultivation. However, land was over-utilized. These observations underscore the presence of inefficiencies in the utilization of

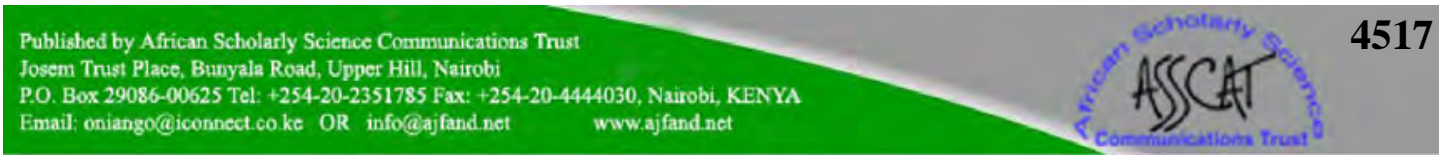


resources in cocoa farming. Over utilization of forest land for cocoa production means that forest land is over exploited for cocoa production since marginal cocoa income from land expansion is relatively smaller than the marginal cost of land per unit area. Increasing cocoa output through land expansion is costly due to scarcity of forest land. This implies that cocoa production could be based on techniques that would save forest land. However, once land is used for cocoa cultivation, its size cannot be reduced easily both in the short and long run. Therefore, it would be better to increase productivity by fertilizer application and control of soil erosion to improve soil fertility. Alternatively, the reduction in land area under cocoa could have a negative impact on cocoa output in the short run since cocoa farmers were operating in an area of increasing returns to scale of the production function. Therefore, one can replant the old cocoa farms with high yielding cocoa variety or more profitable alternative crops to maximize the overall farm profit.

For the study's limitation, relevant variables such as labour, the concept of opportunity costs and risk were not captured in the model. The study could not also consider the spending preferences of the cocoa farmers and focused mainly on cocoa production and not on other crops cultivated as well as household activity engaged in by farmers in the model. The statistically non-significance of the sigma squared and gamma parameters did not allow the researchers to analyze the socio-economic determinants of inefficiencies in cocoa production. It is hoped that a study will be designed and conducted to address these limitations.

\section{CONCLUSIONS AND RECOMMENDATIONS}

In conclusion, the main purpose of this study was to analyze the efficiency of resource utilization in cocoa production of cocoa farmers in Ghana to provide information for effective adjustment of resource use on cocoa farms and policy. The estimation of the Cobb-Douglas production function demonstrated that the coefficients or elasticities of household size, farm size, insecticides, fungicides and fertilizer had statistically significant and positive impact on cocoa output, implying that they are important in increasing cocoa production. The measurement of the marginal physical product of the household size, farm size, insecticides, fungicides and fertilizer indicated positive values re-emphasizing the importance of these factors in cocoa production. The study also observed some inefficiency in the use of resources in cocoa farming based on the fact that some factors of production were underutilized while others were overutilized.

It is recommended that:

- Government should focus its effort on the CODAPEC and Hitech programmes for assisting cocoa farmers in spraying their farms with insecticides and fungicides for pests and disease control, as well as application of fertilizer to improve soil fertility. Still, the constraints in the implementation of these programmes should be addressed. 


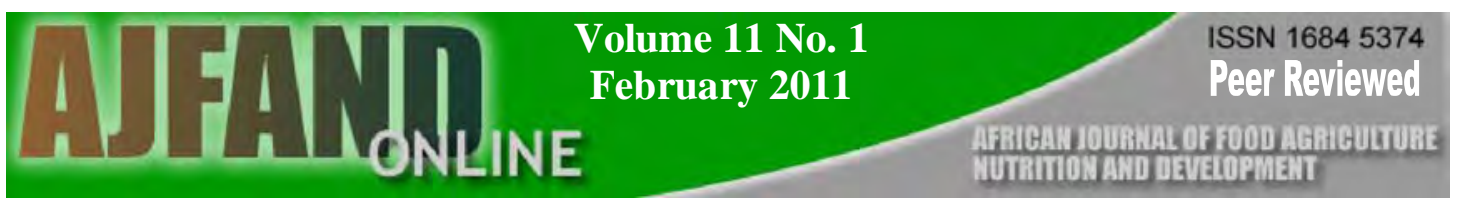

- Farmers are advised to involve more adult household members in their farming activities to increase cocoa output.

- Farmers should increase the use of insecticides, fungicides and fertilizer on their farms as recommended by CRIG.

- Farmers should reduce the excessive use of forest land to prevent deforestation through increased land productivity instead of land expansion to ensure efficient use of land in cocoa production. They can replant the old cocoa farms with high yielding cocoa variety or more profitable alternative crops to maximize the overall farm profit.

- Government should educate farmers on the harmful environmental impacts of their farm activities associated with the use of chemicals and how to avoid them to ensure sustainable cocoa production.

\section{ACK NOWLEDGEMENT}

The support provided by the technical staff, Mr. L. K. Akuffo, Mr. S. Duodu and Mr. Patric Zeal, all of the Social Science and Statistics Unit (SSSU) of Cocoa Research Institute of Ghana (CRIG) is gratefully acknowledged. This paper/publication, CRIG/02/2010/045/002, is published by kind permission of the Executive Director of CRIG, Tafo. 
Table 1: Summary statistics of output and input variables in cocoa production and household characteristics of cocoa farmers

\begin{tabular}{|c|c|c|c|c|c|}
\hline Variable & M ean & $\begin{array}{l}\text { Standard } \\
\text { Deviation }\end{array}$ & M inimum & M aximum & $\begin{array}{l}\text { Sample } \\
\text { size(n) }\end{array}$ \\
\hline \multicolumn{6}{|l|}{ Cocoa Production } \\
\hline Cocoa output (kg) & 797.4 & 912.1 & 31.3 & $5,937.5$ & 257 \\
\hline Cocoa farm size(ha) & 3.0 & 3.7 & 0.4 & 36 & 296 \\
\hline $\begin{array}{l}\text { Quantity of } \\
\text { insecticides(litres) }\end{array}$ & 6.6 & 9.3 & 0.2 & 60.0 & 207 \\
\hline $\begin{array}{l}\text { Quantity of fungicides } \\
\text { (satchets) }\end{array}$ & 47.9 & 65.9 & 0.5 & 380.0 & 157 \\
\hline $\begin{array}{l}\text { Quantity of fertilizer } \\
\text { (bags) }\end{array}$ & 5.4 & 5.1 & 1 & 45 & 101 \\
\hline \multicolumn{6}{|l|}{$\begin{array}{l}\text { Household } \\
\text { Characteristics }\end{array}$} \\
\hline $\begin{array}{l}\text { Age of cocoa farmer } \\
\text { (yrs.) }\end{array}$ & 51.5 & 15.2 & 15 & 86 & 300 \\
\hline $\begin{array}{l}\text { Working experience } \\
\text { (yrs.) }\end{array}$ & 19.6 & 13.7 & 2 & 65 & 297 \\
\hline Household size & 8.5 & 5.6 & 1 & 50 & 298 \\
\hline $\begin{array}{l}\text { Number of adults } \\
\text { working on cocoa } \\
\text { farm }\end{array}$ & 3.3 & 2.8 & 1 & 19 & 197 \\
\hline Educational status & 2.8 & 1.2 & 1 & 2 & 298 \\
\hline Gender & 1.2 & 0.4 & 1 & 2 & 300 \\
\hline Cocoa income (GH $\phi)$ & 717.68 & 820.87 & 28.12 & $5,343.75$ & 257 \\
\hline
\end{tabular}


Table 2: Summary statistics of farm size of other crops planted by cocoa farmers

\begin{tabular}{|c|c|c|c|c|c|}
\hline CROP & $\begin{array}{l}\text { Mean Farm Size } \\
(\mathrm{Ha})\end{array}$ & $\begin{array}{l}\text { Standard } \\
\text { Deviation }\end{array}$ & $\begin{array}{l}\text { Minimum } \\
(\mathrm{Ha})\end{array}$ & $\begin{array}{l}\text { Maximum } \\
(\mathrm{Ha})\end{array}$ & $\begin{array}{l}\text { Number of } \\
\text { Farms (N) }\end{array}$ \\
\hline \multicolumn{6}{|l|}{ Food crop } \\
\hline Plantain & 1.2 & 1.77 & 0.2 & 4.4 & 97 \\
\hline Cassava & 0.8 & 1.04 & 0.2 & 3.2 & 62 \\
\hline Banana & 0.8 & - & 0.8 & 0.8 & 1 \\
\hline Cocoyam & 1.1 & 1.65 & 0.4 & 4.4 & 25 \\
\hline Maize & 1.1 & 1.84 & 0.4 & 4.4 & 35 \\
\hline Groundnut & 0.2 & - & 0.2 & 0.2 & 1 \\
\hline Ginger & 1.2 & - & 1.2 & 1.2 & 1 \\
\hline Okro & 0.9 & 0.4 & 0.8 & 1.0 & 2 \\
\hline Pineapple & 1.0 & - & 0.8 & 1.2 & 2 \\
\hline Rice & 1.2 & - & 1.2 & 1.2 & 1 \\
\hline Yam & 0.4 & - & 0.4 & 0.4 & 2 \\
\hline Sub-total & 1.1 & 1.59 & 6.6 & 22.4 & 229 \\
\hline \multicolumn{6}{|l|}{ Other Tree Crop } \\
\hline Coffee & 1.2 & - & 1.2 & 1.2 & 1 \\
\hline Oil palm & 2.2 & 5.16 & 0.1 & 18.0 & 117 \\
\hline Citrus & 1.8 & 2.35 & 0.4 & 8.0 & 31 \\
\hline Coconut & 4.0 & - & 4.0 & 4.0 & 1 \\
\hline Teak & 0.8 & - & 0.8 & 0.8 & 1 \\
\hline Sub-total & 2.1 & 4.72 & 6.5 & 32.0 & 151 \\
\hline $\begin{array}{l}\text { Total (excluding } \\
\text { cocoa) }\end{array}$ & 1.5 & 3.23 & 13.3 & 117.6 & $380 *$ \\
\hline
\end{tabular}

Note: * The total sample size of crop farms is more than 300 because some farmers had more than one farm. - The standard deviation could not be calculated due to very small sample size (one or two cases observed). Ha = Hectares 
Table 3: Ordinary L east Square (OLS) estimates of C obb-Douglas production function

\begin{tabular}{|l|l|l|l|l|}
\hline Variable & Parameter & Coefficient & $\begin{array}{l}\text { Standard } \\
\text { E rror }\end{array}$ & T-Ratio \\
\hline Constant & $\beta_{0}$ & 4.434 & 0.381 & $11.642^{* * *}$ \\
\hline Household size & $\beta_{1}$ & 0.261 & 0.141 & $1.856^{*}$ \\
\hline Cocoa farm size & $\beta_{2}$ & 0.514 & 0.112 & $4.574^{* * *}$ \\
\hline Quantity of insecticides & $\beta_{3}$ & 0.273 & 0.083 & $3.286^{* * *}$ \\
\hline Quantity of fungicides & $\beta_{4}$ & 0.090 & 0.062 & $1.442^{*}$ \\
\hline Quantity of fertilizer & $\beta_{5}$ & 0.325 & 0.110 & $2.955^{* * *}$ \\
\hline & & & & \\
\hline F test & $\mathrm{F}(5,43)$ & $14.19 * * *$ & & \\
\hline R squared & $\mathrm{R}^{2}$ & 0.623 & & \\
\hline Adjusted R squared & $\mathrm{R}^{2}$ adj. & 0.579 & & \\
\hline Durbin-Watson statistic & $\mathrm{DW}$ & 2.381 & & \\
\hline Sample size & $\mathrm{N}$ & 49 & & \\
\hline
\end{tabular}

Note: $*$ sig. at $10 \%$ level, $* *$ sig. at $5 \%$ level, ***sig. at $1 \%$ level. 
Table 4: $M$ aximum likelihood estimates of the stochastic production frontier (Cobb-Douglas) function

\begin{tabular}{|c|c|c|c|c|}
\hline Variable & Parameter & Coefficient & $\begin{array}{l}\text { Standard } \\
\text { Error }\end{array}$ & T-Ratio \\
\hline Constant & $\beta_{0}$ & 4.701 & 0.481 & $9.776 * * *$ \\
\hline Cocoa farm size & $\beta_{1}$ & 0.393 & 0.154 & $2.549 * *$ \\
\hline Household size & $\beta_{2}$ & 0.231 & 0.144 & $1.603^{*}$ \\
\hline $\begin{array}{l}\text { Quantity of } \\
\text { insecticides }\end{array}$ & $\beta_{3}$ & 0.240 & 0.092 & $2.614 * * *$ \\
\hline $\begin{array}{l}\text { Quantity of } \\
\text { fungicides }\end{array}$ & $\beta_{4}$ & 0.132 & 0.071 & $1.871^{*}$ \\
\hline Quantity of fertilizer & $\beta_{5}$ & 0.411 & 0.129 & $3.199 * * *$ \\
\hline Sigma squared & $\sigma^{2}$ & 0.321 & 0.301 & 1.066 \\
\hline Gamma & $\gamma$ & 0.533 & 0.911 & 0.585 \\
\hline $\begin{array}{l}\text { Log-likelihood } \\
\text { function }\end{array}$ & & -27.592 & & \\
\hline Mean efficiency & & 0.739 & & \\
\hline LR test & & 0.08 & & \\
\hline Sample size & $\mathrm{N}$ & 43 & & \\
\hline
\end{tabular}

Note: $*$ sig. at $10 \%$ level, $* *$ sig. at $5 \%$ level, $* * *$ sig. at $1 \%$ level. 


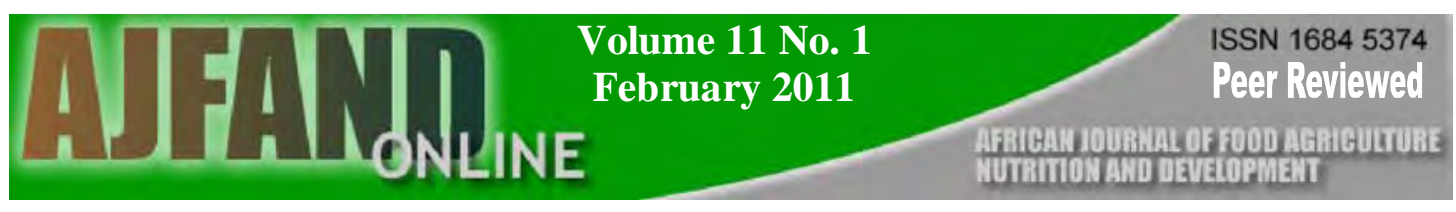

Table 5: Efficiency of resource use in cocoa production

\begin{tabular}{|c|c|c|c|c|c|}
\hline Factor input & $\begin{array}{l}\text { M PP } \\
\text { (kg/unit input) }\end{array}$ & $\begin{array}{l}\text { MVP } \\
(\mathrm{GH} \phi)\end{array}$ & $\begin{array}{l}\text { MFC } \\
(\mathrm{GH} \phi)\end{array}$ & $r=M V P / M F C$ & $\mathrm{D}(\%)$ \\
\hline Household size & 22.64 & 48.90 & 3.50 & 13.97 & 92.84 \\
\hline Cocoa farm size & 126.31 & 272.83 & 500.00 & 0.55 & -83.00 \\
\hline Quantity of insecticides & 30.49 & 65.86 & 25.00 & 2.63 & 62.04 \\
\hline Quantity of fungicides & 1.39 & 3.00 & 0.50 & 6.00 & 83.33 \\
\hline Quantity of fertilizer & 133.11 & 287.52 & 14.70 & 19.56 & 94.89 \\
\hline
\end{tabular}




\section{REFERENCES}

1. Aneani $F$, Anchirinah VM, Asamoah $M$ and $F$ Owusu-Ansah Baseline Socio-Economic and Farm Management Survey. A Final Report for the Ghana Cocoa Farmers' Newspaper Project. New Tafo-Akim, Ghana: Cocoa Research Institute of Ghana (CRIG), 2007.

2. Idiong IC Estimation of Farm Level Technical Efficiency in Small-scale Swamp Rice Production in Cross River State of Nigeria: A Stochastic Frontier Approach. World J . of Agric. Sci. 2007; 3(5): 653-658.

3. Anupama J, Singh RP and R Kumar Technical Efficiency in Maize Production in Madhya Pradesh: Estimation and implications. Agric. Economics Review. 2005; 18: 305-315.

4. Kalirajan KP and RT Shaud Frontier Production Functions and Technical Efficiency Measures. J . of E conomic Surveys. 1999; 13(2): 149-172.

5. Iheanacho AC, Olukosi $\mathrm{JO}$ and AO Ogunbile Economic Efficiency of Resource Use in Millet-Based Cropping Systems in Borno State of Nigeria, Nigerian J . of Tropical Agric. 2000; 2: 33-42.

6. Rahman SA and AB Lawal Economic Analysis of Maize-Based Cropping Systems in Giwa Local Government Area of Kaduna State, Nigeria. An International J. of Agric. Sci., Sci., Environment and Technology. 2003; 3(2): $139-148$.

7. Boyd H W J r, W estfall R and SF Stasch Marketing Research: Text and Cases. Seventh Edition. Homewood, Illinois, USA: Richard D. Irwin, Inc. 2004: 357416.

8. O suala EC Introduction to Research Methodology. Third Edition. AfricanFirst Publishers Limited, Onitsha, Nigeria. 1982: 114 - 136.

9. A neani $F$ and M A samoah Socio-economic Survey on Cocoa Fermentation in Ghana. J . of the G hana Sci. Association. 2004; 6 (2): 90 - 97.

10. Sadhu AN and A Singh Fundamentals of Agricultural Economics. Bombay: $\mathrm{H}$ imalaya Publishing House. 1995: 80-93.

11. Battese GE and TJ Coelli A Model for Technical Inefficiency Effects in Stochastic Frontier Production Function for Panel Data. Empirical Economics. 1995; 20: 325- 332.

12. Chirwa EW Sources of Technical Efficiency among Smallholder Maize Farmers in Southern Malawi. AERC Research Paper 172. African Economic Research Consortium, Nairobi. 2007. 
13. Donkor SA, Tiffin R and C Srinivasan How Efficient is Green Revolution Technology Adoption in Ghana? J . of G hana Sci. Association. 2008; 10 (2): 103-115.

14. Ogundari K Resource Productivity, Allocative Efficiency and Determinants of Technical Efficiency of Rainfed Rice Farmers: A Guide for Food Security Policy in Nigeria. J. of Sustainable Development in Agric. and Environment. 2008; 3(2): 20-33.

15. Seidu Al-hassan Technical Efficiency of Rice Farmers in Northern Ghana. AERC Research Paper 178, African Economic Research Consortium, Nairobi. 2008.

16. Onyenwaku CE "Economics of Irrigation in Crop Production in Nigeria." In: Steven A. Breth (ed.). Issues in African Rural Development 2. African Rural Social Sciences Research Networks. Arlington, USA:Winrock International Institute for Agricultural Development, 1994: 129 - 138.

17. Moses J and EF Adebayo Efficiency of Factors Determining rainfed Rice Production in Ganye Local Government Area, Adamawa State. J . of Sustainable Development in Agric. \& Environment. 2007; 3: 20-30.

18. Udoh EJ and NA Etim Measurement of Farm-Level Efficiency of Water-Leaf (Talinum triangulare) Production Among City Farmers in Akwa Ibom State, Nigeria. J . of Sustainable Development in Agriculture and Environment. 2008; 3(2): 47-54. 